\title{
Nitrogen Transformations in Broiler Litter-Amended Soils
}

\author{
Kokoasse Kpomblekou-A and Andrae Genus \\ Department of Agricultural and Environmental Sciences, Tuskegee University, Tuskegee, AL 36088, USA \\ Correspondence should be addressed to Kokoasse Kpomblekou-A, kka@mytu.tuskegee.edu
}

Received 22 December 2011; Accepted 19 March 2012

Academic Editor: Dexter B. Watts

Copyright ( $\odot 2012$ K. Kpomblekou-A and A. Genus. This is an open access article distributed under the Creative Commons Attribution License, which permits unrestricted use, distribution, and reproduction in any medium, provided the original work is properly cited.

\begin{abstract}
Nitrogen mineralization rates in ten surface soils amended with $\left(200 \mu \mathrm{g} \mathrm{N} \mathrm{g} \mathrm{g}^{-1}\right.$ soil $)$ or without broiler litter were investigated. The soil-broiler litter mixture was incubated at $25 \pm 1{ }^{\circ} \mathrm{C}$ for 28 weeks. A nonlinear regression approach for $\mathrm{N}$ mineralization was used to estimate the readily mineralizable organic $\mathrm{N}$ pools $\left(\mathrm{N}_{0}\right)$ and the first-order rate constant $(k)$. The cumulative $\mathrm{N}$ mineralized in the nonamended soils did not exceed $80 \mathrm{mg} \mathrm{N} \mathrm{kg}^{-1}$ soil. However, in Decatur soil amended with broiler litter 2, it exceeded $320 \mathrm{mg} \mathrm{N} \mathrm{kg}^{-1}$ soil. The greatest calculated $\mathrm{N}_{0}$ of the native soils was observed in Sucarnoochee soil alone $\left(123 \mathrm{mg} \mathrm{NO}_{3}^{-} \mathrm{kg}^{-1}\right.$ soil) which when amended with broiler litter 1 reached $596 \mathrm{mg} \mathrm{N} \mathrm{kg}^{-1}$ soil. The added broiler litter mineralized initially at a fast rate $\left(k_{1}\right)$ followed by a slow rate $\left(k_{2}\right)$ of the most resistant fraction. Half-life of organic $\mathrm{N}$ remaining in the soils alone varied from 33 to 75 weeks and from 43 to 15 weeks in the amended soils. When $\mathrm{N}_{0}$ was regressed against soil organic $\mathrm{N}\left(r=0.782^{* *}\right)$ and $\mathrm{C}\left(r=0.884^{* *}\right)$, positive linear relationships were obtained. The $\mathrm{N}_{0}$ pools increased with sand but decreased with silt and clay contents.
\end{abstract}

\section{Introduction}

In general, nitrogen $(\mathrm{N})$ is said to be the most difficult nutrient to manage in agriculture because of challenges in estimating the amount of $\mathrm{N}$ available for plant uptake and synchronizing $\mathrm{N}$ release from sources to meet a specific crop demand [1]. Even though the Earth's atmosphere contains $78 \% \mathrm{~N}$ in the form of dinitrogen $\left(\mathrm{N}_{2}\right)$ gas, most of this $\mathrm{N}$ is unavailable for plant uptake [2] with the exception of leguminous plants which can fix $\mathrm{N}$. In the plant root zone, $\mathrm{N}$ is present in organic forms, including plant and microbial protein and amino acids, all together forming soil organic matter [3] from which the $\mathrm{N}$ is slowly converted into plant-available forms. During mineralization, organic $\mathrm{N}$ is converted into plant-useable inorganic forms $\left(\mathrm{NH}_{4}{ }^{+}-\right.$ $\mathrm{N}$ and, $\left.\mathrm{NO}_{3}{ }^{-}-\mathrm{N}\right)$ that are released into soil and subjected to various fates. For farmers in general and organic farmers in particular, $\mathrm{N}$ mineralization is an important process to understand because several environmental conditions govern this process [3]. Presently, there is an array of commercial inorganic $\mathrm{N}$ fertilizers available; however, their costs are prohibitory and out of range for many limited resource farmers. Thus, a careful management of organic
$\mathrm{N}$ sources is one of the most important priorities for farmers; this in turn will limit unfavorable $\mathrm{N}$ losses into the environment.

Because of the rapid growth of the organic farming segment of the United States agriculture, there is a high demand for alternative plant nutrient sources, especially, organic sources. It is estimated that organic produce sales reached approximately $\$ 23.0$ billion in 2009 [4] from 2.6 billion in 1997 [5]. This rapid growth in organic food demand urges researchers to obtain a more thorough understanding of organic amendment in organic farming systems. The United States poultry industry produced 9.2 billion broiler chickens and 90.6 billion eggs in 2007 with nearly $82 \%$ of the broilers and $31 \%$ of the eggs produced in the southeastern states of Georgia, Arkansas, Alabama, Mississippi, and North Carolina. These five states account for approximately $60 \%$ of all broiler meat produced in the United States [6, 7]. Broiler production in the United States has been transformed dramatically from small backyard operations to more integrated farms. As time progressed, broiler production became an industry that established itself in the South due to favorable climate, low labor costs, and advantages in feed production [8]. In 2009, approximately 
8.6 billion broiler chickens equaling 50 billion pounds valued at $\$ 22$ billion were raised in the USA, and the state of Alabama accounted for approximately $12 \%$ of this total [9]. This robust broiler industry generates substantial quantities of poultry litter as waste at a rate of 1 to 1.4 tons per 1000 birds. It is estimated that broiler litter in Alabama contains $41.1 \mathrm{~g} \mathrm{~kg}^{-1}$ Kjeldahl N [10]. The broiler litter generated has historically been applied to pasture and agricultural land in close proximity to poultry production facilities [11]. Consequently, negative environmental impacts of these waste products are a major concern worldwide. One major problem that occurs is the presence and buildup of trace elements in soil over time [12]. Despite the fact that broiler litter contains trace elements that may affect $\mathrm{N}$ transformations in soils; it remains a cheap organic fertilizer used in organic farming systems.

Excessive applications of broiler litter to farmlands have resulted in $\mathrm{NO}_{3}{ }^{-}$contamination of both ground and surface water bodies. Accurate estimates of $\mathrm{N}$ availability from broiler litter is a prerequisite to determine application rates necessary for optimum plant growth and minimal $\mathrm{NO}_{3}{ }^{-}$ leaching. A method to estimate the amount of $\mathrm{N}$ available in broiler litter to increase crop yields and reduce $\mathrm{N}$ losses to the environment was assessed [13]. In this method, broiler litter application rates were based on predicted available $\mathrm{N}$ (PAN). It was assumed that $80 \%$ of the inorganic $\mathrm{N}$ in the broiler litter would be recovered and $60 \%$ of the organic $\mathrm{N}$ would be mineralized within 140 days. In addition, other methods used to predict $\mathrm{N}$ availability from broiler litter include complex mechanistic and simple kinetic models [14]. Mechanistic models are more process based and require large amounts of input data. On the other hand, kinetic models rely on laboratory incubations to obtain certain parameters; however, these kinetic models do not account for $\mathrm{N}$ turnover processes [15]. The various types of kinetic models used to describe inorganic $\mathrm{N}$ production from soil alone or amended with organic material include sigmoid, hyperbolic, single exponential, and linear models $[16,17]$. However, explanations behind the theoretical implications of the parameters in these various mathematical equations have been limited [18]. Therefore, the two first-order kinetic models that remain widely used include the single [19] and double [20] exponential models.

The Stanford and smith (1972) model is represented by

$$
\mathrm{N}_{\mathrm{m}}=\mathrm{N}_{0}\left(1-\mathrm{e}^{-k t}\right) \text {, }
$$

where, $\mathrm{N}_{\mathrm{m}}$ is the cumulative mineral- $\mathrm{N}\left(\mathrm{mg} \mathrm{N} \mathrm{kg}^{-1}\right.$ soil) at time $t . \mathrm{N}_{0}$ is defined as the potentially mineralizable $\mathrm{N}$ and $k$ as the mineralization rate constant.

The double exponential model separates the mineralizable organic $\mathrm{N}$ into active and slow pools and is represented by

$$
\mathrm{N}_{\mathrm{m}}=\mathrm{N}_{0}\left(1-\mathrm{e}^{-k_{0} t}\right)+\mathrm{N}_{1}\left(1-\mathrm{e}^{-k_{1} t}\right),
$$

where $\mathrm{N}_{\mathrm{m}}$ is the cumulative amount of $\mathrm{N}$ mineralized at time $t, \mathrm{~N}_{0}$, and $\mathrm{N}_{1}$ are the sizes of the active and slow pools of mineralizable $\mathrm{N}$, respectively; $k_{0}$ and $k_{1}$ are the corresponding mineralization rate constants for each pool.
In the study reported here, the single exponential model [19] was used. The model suggests that the potentially mineralizable $\mathrm{N}\left(\mathrm{N}_{0}\right)$ of a soil and its rate constant $(k)$ can be estimated by incubating the soil at optimum conditions and measuring the $\mathrm{N}$ mineralized $\left(\mathrm{N}_{\mathrm{m}}\right)$ and time of incubation $(t)$. The main assumption is that organic $\mathrm{N}$ mineralization at optimum temperature and moisture follows first-order kinetics. The objectives of the study were to (1) determine $\mathrm{N}$ mineralization rates in ten Alabama soils amended and nonamended with broiler litter, (2) compare potentially mineralizable organic $\mathrm{N}$ pools in the soils, (3) compare halflife of $\mathrm{N}$ remaining in the soils, and (4) establish relationships between the soils' potentially mineralizable organic $\mathrm{N}$ and soil properties.

\section{Materials and Methods}

Alabama surface $(0-15 \mathrm{~cm})$ soil samples were collected from Barbour County (Troup soil), Bullock County (Maytag and Sucarnoochee soils), Dekalb County (Colbert, Hartsells, and Linker soils), Coffee County (Dothan soil), Talladega County (Decatur soil), and Tallapoosa County (Appling and Cecil soils). The physical and chemical properties of the soils are presented in Table 1. Following sampling, the soils were airdried and ground to pass through a $2 \mathrm{~mm}$ sieve. A subsample was finely ground to pass a 100 -mesh $(<149-\mu \mathrm{m})$ sieve for analysis of total C and N by Vario EL III Automated Analyzer (CHNS Analyzer, Hanau, Germany) using a combustion method. In the analysis reported in Table 1 , soil $\mathrm{pH}$ was measured (soil: water ratio $1: 2.5)$ using a glass electrode, organic C by the Mebius method [21], total N by SemimicroKjeldahl procedure [22], inorganic $\mathrm{N}$ by steam distillation [23], and partial-size distribution by the pipette method [24]. Selected properties of the broiler litter samples used in the study are shown in Table 2 where total $\mathrm{C}$ and $\mathrm{N}$ were determined by the elemental CHNS Analyzer (Vario EL III Elemental Analyzer, Hanau, Germany). The $\mathrm{pH}$ was determined (broiler litter: water ratio 1:5) using a glass electrode. The $\mathrm{NH}_{4}{ }^{+}-\mathrm{N}$ and $\mathrm{NO}_{3}{ }^{-}-\mathrm{N}$ were determined by steam distillation [23]. Properties of the soil and the broiler litter samples shown in Tables 1 and 2, respectively, were previously reported [25].

The experimental setup was a $10 \times 3$ factorial in a completely randomized design. The treatments included a control (soil alone with no broiler litter added), soilamended with broiler litter 1, and soil-amended with broiler litter 2. The broiler litter was added at a rate to give a concentration of $200 \mu \mathrm{g} \mathrm{N} \mathrm{g}^{-1}$ soil. A $20 \mathrm{~g}$ soil sample $(<2-$ $\mathrm{mm}, \mathrm{OD}$ ) and an equal amount of acid-washed silica sand were weighted into a weighing dish and mixed thoroughly. Before the experiment, the silica sand was washed in $10 \%$ $\mathrm{HCl}$ solution and let to stand for 1 hour after which the silica sand was washed three times in deionized water. The washed silica sand was allowed to dry under the hood for several days. A sample of the silica sand was analyzed for inorganic $\mathrm{N}$ by steam distillation and showed absence of $\mathrm{NH}_{4}{ }^{+}-$and $\mathrm{NO}_{3}{ }^{-}-\mathrm{N}$. The soil-silica sand mixture was then treated with broiler litter 1 or 2 . A thin glass wool was 
TABLE 1: Selected properties of the soils used ${ }^{\dagger}$.

\begin{tabular}{|c|c|c|c|c|c|c|c|c|}
\hline \multirow{4}{*}{$\begin{array}{l}\text { Soil series }^{\dagger} \\
\text { Appling }\end{array}$} & \multirow{4}{*}{$\begin{array}{l}\mathrm{pH} \\
5.95\end{array}$} & \multirow{4}{*}{$\begin{array}{r}\text { Organic Carbon } \\
26.4\end{array}$} & \multirow{4}{*}{$\begin{array}{c}\text { Total nitrogen } \\
3.90\end{array}$} & \multirow{3}{*}{\multicolumn{2}{|c|}{$\begin{array}{c}\text { Inorganic } \mathrm{N} \\
\mathrm{NH}_{4}{ }^{+}-\left(\mathrm{NO}_{2}^{-}+\mathrm{NO}_{3}{ }^{-}\right)-\mathrm{N} \\
\mathrm{mg} \mathrm{kg}^{-1}\end{array}$}} & \multicolumn{3}{|c|}{ Texture } \\
\hline & & & & & & \multirow{3}{*}{$\begin{array}{c}\text { Clay } \\
75\end{array}$} & \multirow{3}{*}{$\frac{\begin{array}{c}\text { Silt } \\
\mathrm{g} \mathrm{kg}^{-1}\end{array}}{125}$} & \multirow{3}{*}{$\begin{array}{r}\text { Sand } \\
800\end{array}$} \\
\hline & & & & & & & & \\
\hline & & & & 14.3 & 9.57 & & & \\
\hline Cecil & 5.87 & 19.0 & 3.38 & 14.4 & 20.8 & 75 & 225 & 700 \\
\hline Colbert & 6.05 & 6.88 & 2.53 & 13.1 & 23.0 & - & 125 & 875 \\
\hline Decatur & 5.90 & 14.3 & 3.91 & 8.91 & 8.73 & - & 100 & 900 \\
\hline Dothan & 6.48 & 9.37 & 2.57 & 12.0 & 21.2 & 75 & 650 & 275 \\
\hline Hartsells & 6.06 & 9.58 & 2.67 & 3.91 & 5.39 & 125 & 300 & 575 \\
\hline Maytag & 5.95 & 7.37 & 2.55 & 2.55 & 3.05 & 125 & 325 & 550 \\
\hline Linker & 6.31 & 9.71 & 2.73 & 3.10 & 7.02 & 25 & 350 & 625 \\
\hline Sucarnoochee & 5.91 & 11.4 & 2.82 & 6.87 & 3.39 & 75 & 475 & 450 \\
\hline Troup & 6.64 & 20.1 & 3.30 & 2.16 & 5.07 & 125 & 75 & 800 \\
\hline
\end{tabular}

${ }^{\dagger}$ Appling: Fine, kaolinitic thermic kanapludult; Cecil: Fine, kaolinitic thermic, Typic kanapludults; Colbert; Fine, smetitic, thermic Vertic Hapludults; Decatur; Clayey, kaolinitic thermic Rhodic Paleudults; Dothan; Fine-loamy, siliceous, thermic Plinthic Paleudults; Hartsells; Fine-loamy, siliceous subactive thermic Typic Hapludults; Maytag; Fine montmorillonitic, thermic, oxyaquic Hapluderts; Linker; Fine-loamy, siliceous semiactive thermic Typic Hapludults; Sucarnoochee; montmorillonitic, thermic chromic Epiaqurand; Troup; Loamy, siliceous, Thermic Grossarenic Paleudults. From Sissoko and Kpomblekou-A $2010[25]$.

TABLE 2: Selected properties of the broiler litter used ${ }^{\dagger}$.

\begin{tabular}{|c|c|c|c|c|c|c|c|c|}
\hline \multirow{3}{*}{ Broiler litter ID } & \multirow{3}{*}{$\mathrm{pH}$} & \multirow{3}{*}{ Organic C } & \multirow{3}{*}{ Total N } & \multirow{2}{*}{\multicolumn{2}{|c|}{$\begin{array}{l}\text { Inorganic } \mathrm{N} \\
\qquad\left(\mathrm{NO}_{2}{ }^{-}+\mathrm{NO}_{3}^{-}\right)\end{array}$}} & \multirow{3}{*}{$\mathrm{C} / \mathrm{N}$} & \multirow{3}{*}{ Bedding material } & \multirow{3}{*}{$\begin{array}{c}\text { Litter age } \\
\text { Month }\end{array}$} \\
\hline & & & & & & & & \\
\hline & & & & \multicolumn{2}{|c|}{$\left(\mathrm{NU}_{2}+\mathrm{NU}_{3}\right)$} & & & \\
\hline 1 & 8.4 & 229 & 27.5 & 1.61 & 1.03 & 8.32 & Pine sawdust & 9 \\
\hline 2 & 8.6 & 351 & 46.1 & 4.39 & 1.95 & 7.61 & Peanut hulls & 9 \\
\hline
\end{tabular}

${ }^{\dagger}$ From Kpomblekou-A [10].

inserted at the bottom of a leaching tube to retain the mixture. To prevent any disturbance of the soil during the leaching procedure, a thin glass wool pad was also placed on the top of the mixture in the leaching tube. The leaching tube was placed on a flask and immediately leached with $100 \mathrm{~mL}$ of $5 \mathrm{mM} \mathrm{CaCl}_{2}$ to remove any initial inorganic $\mathrm{N}$ (time zero). A suction of $60 \mathrm{~cm} \mathrm{Hg}(6 \mathrm{kpa})$ was applied to remove the remaining solution. The volume of the leachate obtained was adjusted to $100 \mathrm{~mL}$ with deionized water. The leaching tube was covered with parafilm and a small hole was inserted for aeration and placed in an incubator (Low Temperature Incubator 815, Precision Scientific Winchester, VA) at $25 \pm 1^{\circ} \mathrm{C}$ for 22 weeks. The inorganic $\mathrm{N}$ mineralized in the leaching tube was leached every two weeks for 28 weeks with $100 \mathrm{~mL} \mathrm{CaCl}_{2}(5 \mathrm{mM})$ and filtered through a membrane filter $(0.5 \mu \mathrm{m}$, Osomics Inc., Minnetonka, MN). The filtrate was analyzed for $\mathrm{NH}_{4}{ }^{+}-\mathrm{N}$ and $\left(\mathrm{NO}_{2}{ }^{-}+\mathrm{NO}_{3}{ }^{-}\right)-\mathrm{N}$ by steam distillation [23]. Controls for each soil without broiler litter were included. Results presented are average of duplicate samples.

2.1. Model Description and Statistical Analysis. The nonlinear regression [26] approach for $\mathrm{N}$ mineralization in (1) was used to estimate the readily mineralizable organic pools $\left(\mathrm{N}_{0}\right)$ in the broiler litter and the first-order rate constant $(k)$. The Statistical Analysis System (SAS) computer language was used to calculate $\mathrm{N}_{0}$ and $k$ [27]. From the slopes of the linear segments of curves obtained by plotting the natural log of organic $\mathrm{N}$ remaining against time [28], the decomposition rates $\left(k_{i}\right)$ of the organic $\mathrm{N}$ pool was calculated. The half-life $\left(t_{1 / 2}\right)$ of the most resistant $\mathrm{N}$ fraction in the organic materials was calculated by using the $k_{i}$ value of the resistant fraction of the broiler litter samples $\left(t_{1 / 2}=0.693 / k_{i}\right)$. The fitting of the mathematical models was done using SAS-ProcNLIN [29], an interactive method using MARQUADART [30] algorithm. Estimated potentially mineralizable organic $\mathrm{N}$ $\left(\mathrm{N}_{0}\right)$ values were used in a $10 \times 3$ factorial arrangement and analyzed by SAS-Proc GLM. Therefore, when soil differences or treatment differences were detected base on overall analysis of variance, least significant difference (LSD) was used to evaluate differences between treatments and between soils. However, in this study, no soil by treatment interactions was detected.

\section{Results and Discussion}

3.1. Nitrogen Mineralization. The total $\mathrm{N}$ content of the soils varied considerably (Table 1 ). These variations are attributed to climate, vegetation, and topography [31] that are major components of soil formation factors. In cultivated soils, total $\mathrm{N}$ content tends to decline over time if external organic $\mathrm{N}$ sources are not incorporated into the soil to compensate for losses due to increasing microbial $\mathrm{N}$ mineralization. In general, $\mathrm{N}$ mineralization increases as temperature rises to a 
TABle 3: Organic carbon, sulfur, and total nitrogen contents of soil-amended with broiler litter sample 1 or 2 before aerobic incubation studies $^{\dagger}$.

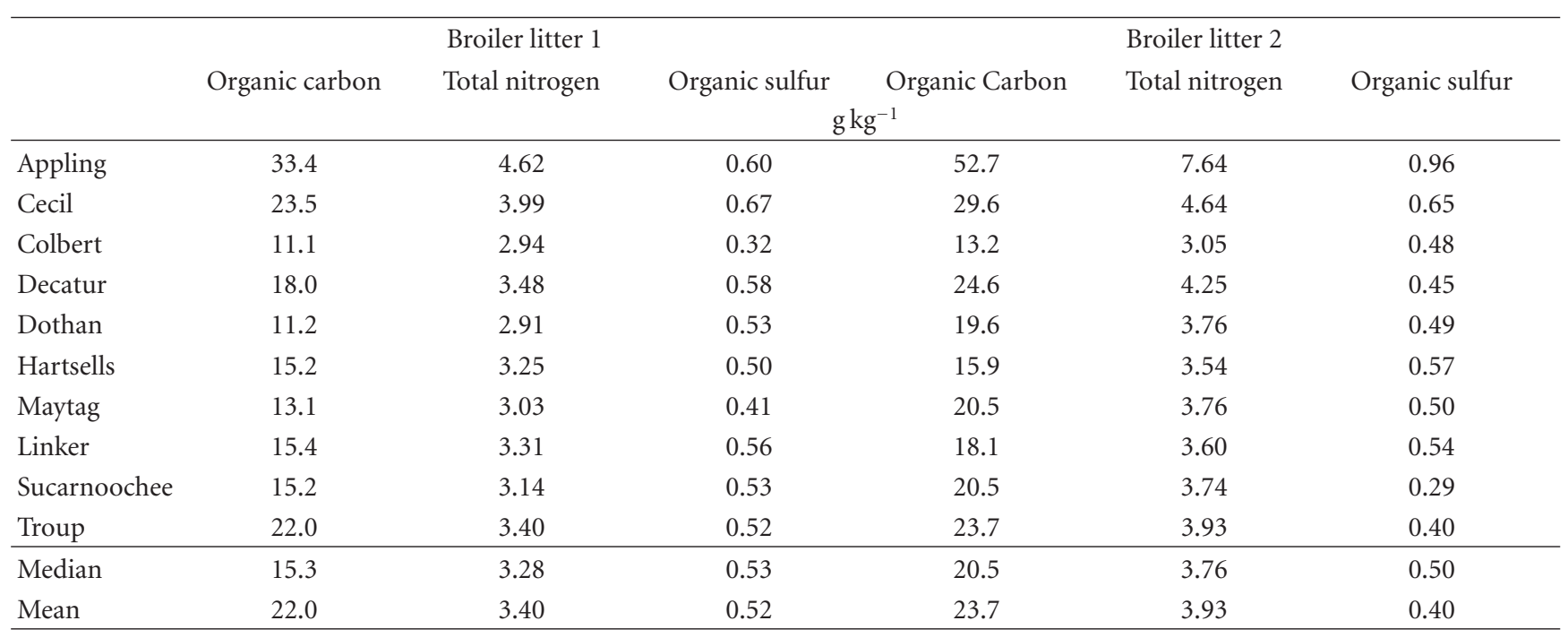

point where microbial growth is reduced [32]. The amount of total $\mathrm{N}$ present in the soil after addition of the broiler litter samples is shown in Table 3. The soil-broiler litter mixture was ground to pass through a $100-$ mesh $(<149-\mu \mathrm{m})$ and a subsample was analyzed for organic C and N. Data obtained from this analysis were used in calculating the remaining organic $\mathrm{N}$ in the soils at the end of incubation period. The results showed an increase in organic $\mathrm{C}$ and $\mathrm{N}$ contents of the soil-broiler litter mixture. However, the increase varied among the ten soil samples analyzed. The total $\mathrm{N}$ content of the mixtures ranged from $2.91 \mathrm{~g} \mathrm{~kg}^{-1}$ in Dothan soil to $4.62 \mathrm{~g} \mathrm{~kg}^{-1}$ in Appling soil treated with broiler litter 1 (Table 3). The analysis also showed that for soils treated with broiler litter 1 , the median for total $\mathrm{N}$ was $3.28 \mathrm{~g} \mathrm{~kg}^{-1}$ with a mean of $3.40 \mathrm{~g} \mathrm{~kg}^{-1}$. However, for the same soils treated with broiler litter 2 , the median and the mean were 3.76 and $3.93 \mathrm{~g} \mathrm{~kg}^{-1}$, respectively.

Among the ten soils used in this study, the cumulative ammonium-N $\left(\mathrm{NH}_{4}{ }^{+}-\mathrm{N}\right)$ produced in the nonamended soils were $21.2,22.6,23.7,24.3,26.5,26.9,27.0,27,35.8$, and $50.5 \mathrm{mg} \mathrm{N} \mathrm{kg}^{-1}$ soil for Appling, Hartsells, Colbert, Linker, Decatur, Maytag, Troup, Dothan, Sucarnoochee, and Cecil soil, respectively, after 28 weeks of incubation (data not shown). On the other hand, soils amended with broiler litter 2 had significantly greater amounts of $\mathrm{NH}_{4}{ }^{+}-$ $\mathrm{N}$ produced. For example, Maytag, Cecil, and Sucarnoochee soils amended with broiler litter 2 showed the highest amount of $\mathrm{NH}_{4}{ }^{+}-\mathrm{N}$ produced after 28 weeks of incubation with 325,326 , and $366 \mathrm{mg} \mathrm{kg}^{-1}$ soil, respectively. However, the total amount of $\mathrm{NO}_{3}{ }^{-}-\mathrm{N}$ mineralized in the soils alone was 27.5 in Hartsells, 43.5 in Troup, 49.6 in Dothan, 62.2 in Appling, 58.1 in Colbert, 65.7 in Maytag, 69.3 in Decatur, 85.7 in Linker, 106 in Cecil, and $111 \mathrm{mg} \mathrm{N} \mathrm{kg}^{-1}$ soil in Sucarnoochee soil after 28 weeks of incubation (data not shown). In addition, the amount of $\mathrm{NO}_{3}{ }^{-}-\mathrm{N}$ mineralized also varied with soil types and broiler litter samples. For Appling soil amended with broiler litter 1, the total amount of $\mathrm{NO}_{3}{ }^{-}-\mathrm{N}$ released at 14 weeks of incubation was about $7.42 \mathrm{mg} \mathrm{N} \mathrm{kg}^{-1}$ soil while in that same soil amended with broiler litter $2, \mathrm{NO}_{3}{ }^{-}-\mathrm{N}$ released was $8.31 \mathrm{mg} \mathrm{N} \mathrm{kg}^{-1}$ soil. In contrast, $\mathrm{NO}_{3}{ }^{-}-\mathrm{N}$ released in Cecil soil amended with broiler litter 1 at 14 weeks was $8.72 \mathrm{mg} \mathrm{N} \mathrm{kg}^{-1}$ soil while that released in Cecil soil amended with broiler litter 2 was only $4.03 \mathrm{mg} \mathrm{kg}^{-1}$. The amount of $\mathrm{NO}_{3}{ }^{-}-\mathrm{N}$ released in the ten soils were significantly greater than those of $\mathrm{NH}_{4}{ }^{+}-$ $\mathrm{N}$ released after 28 weeks of incubation. The cumulative amount of $\mathrm{NO}_{3}{ }^{-}-\mathrm{N}$ mineralized in soils amended with broiler litter 1 after 28 weeks of incubation varied from 131 in Troup to $269 \mathrm{mg} \mathrm{N} \mathrm{kg}^{-1}$ soil in Decatur soil, respectively. On the other hand, the total $\mathrm{NO}_{3}{ }^{-}-\mathrm{N}$ nitrified in soils amended with broiler litter 2 after 28 weeks of incubation ranged from 120 in Dothan soil to $248 \mathrm{mg} \mathrm{kg}^{-1}$ soil in Appling and Sucarnoochee soil, respectively. In addition, Linker soil amended with broiler litter 1 or 2 nitrified the same amounts of $\mathrm{N}$ with $163 \mathrm{mg} \mathrm{N} \mathrm{kg}^{-1}$ soil, respectively. Only Sucarnoochee and Troup soils showed higher amounts of $\mathrm{NO}_{3}{ }^{-}-\mathrm{N}$ mineralized when amended with broiler litter 1 than with broiler litter 2 . In those soils mineralization varied from 231 to 248 in Sucarnoochee amended with broiler litter 1 and 2, and from 131 to $138 \mathrm{mg} \mathrm{N} \mathrm{kg}^{-1}$ soil when Troup was amended with broiler litter 1 and 2, respectively. All remaining soils showed similar trends with broiler litter 1 mineralizing higher amounts of $\mathrm{N}$ as $\mathrm{NO}_{3}{ }^{-}-\mathrm{N}$ than those amended with broiler litter 2 .

3.2. Nitrogen Mineralization Models. The trends of $\mathrm{N}$ mineralization from broiler litter added to ten Alabama soils were similar to those reported for Iowa soils amended with leguminous crops [33]. In this study, the differences in organic $\mathrm{N}$ mineralized may be attributed to the resistance of organic $\mathrm{N}$ fractions in the different broiler litter samples. In general, the amounts of $\mathrm{N}$ mineralized in the broiler litteramended soils increased gradually but at a decreasing rate. Thus, mineralization of organic $\mathrm{N}$ added to soils starts with 
TABLE 4: Regression equations (for curves in Figures 1-5) for organic N mineralized in selected Alabama soils.

\begin{tabular}{|c|c|c|c|}
\hline \multirow{2}{*}{ Soil series } & \multicolumn{3}{|c|}{ Treatment specified $^{\dagger}$} \\
\hline & Soil alone & Soil + broiler litter 1 & Soil + broiler litter 2 \\
\hline Appling & $\mathrm{N}_{\mathrm{m}}=85.3\left(1-\mathrm{e}^{-0.1320 t}\right)$ & $\mathrm{N}_{\mathrm{m}}=252\left(1-\mathrm{e}^{-0.1730 t}\right)$ & $\mathrm{N}_{\mathrm{m}}=283\left(1-\mathrm{e}^{-0.0910 t}\right)$ \\
\hline Cecil & $\mathrm{N}_{\mathrm{m}}=120\left(1-\mathrm{e}^{-0.0405 t}\right)$ & $\mathrm{N}_{\mathrm{m}}=251\left(1-\mathrm{e}^{-0.0494 t}\right)$ & $\mathrm{N}_{\mathrm{m}}=331\left(1-\mathrm{e}^{-0.0315 t}\right)$ \\
\hline Colbert & $\mathrm{N}_{\mathrm{m}}=76.7\left(1-\mathrm{e}^{-0.406 t}\right)$ & $\mathrm{N}_{\mathrm{m}}=360\left(1-\mathrm{e}^{-0.0405 t}\right)$ & $\mathrm{N}_{\mathrm{m}}=369\left(1-\mathrm{e}^{-0.0406 t}\right)$ \\
\hline Decatur & $\mathrm{N}_{\mathrm{m}}=86.9\left(1-\mathrm{e}^{-0.0627 t}\right)$ & $\mathrm{N}_{\mathrm{m}}=356\left(1-\mathrm{e}^{-0.063 t}\right)$ & $\mathrm{N}_{\mathrm{m}}=405\left(1-\mathrm{e}^{-0.0619 t}\right)$ \\
\hline Dothan & $\mathrm{N}_{\mathrm{m}}=66.9\left(1-\mathrm{e}^{-0.0865 t}\right)$ & $\mathrm{N}_{\mathrm{m}}=131\left(1-\mathrm{e}^{-0.0877 t}\right)$ & $\mathrm{N}_{\mathrm{m}}=167\left(1-\mathrm{e}^{-0.0854 t}\right)$ \\
\hline Hartsells & $\mathrm{N}_{\mathrm{m}}=47.9\left(1-\mathrm{e}^{-0.0620 t}\right)$ & $\mathrm{N}_{\mathrm{m}}=208\left(1-\mathrm{e}^{-0.0614 t}\right)$ & $\mathrm{N}_{\mathrm{m}}=294\left(1-\mathrm{e}^{-0.0625 t}\right)$ \\
\hline Linker & $\mathrm{N}_{\mathrm{m}}=102\left(1-\mathrm{e}^{-0.0801 t}\right)$ & $\mathrm{N}_{\mathrm{m}}=195\left(1-\mathrm{e}^{-0.0819 t}\right)$ & $\mathrm{N}_{\mathrm{m}}=209\left(1-\mathrm{e}^{-0.0783 t}\right)$ \\
\hline Maytag & $\mathrm{N}_{\mathrm{m}}=82.8\left(1-\mathrm{e}^{-0.0793 t}\right)$ & $\mathrm{N}_{\mathrm{m}}=221\left(1-\mathrm{e}^{-0.0764 t}\right)$ & $\mathrm{N}_{\mathrm{m}}=217\left(1-\mathrm{e}^{-0.0821 t}\right)$ \\
\hline Sucarnoochee & $\mathrm{N}_{\mathrm{m}}=123\left(1-\mathrm{e}^{-0.0516 t}\right)$ & $\mathrm{N}_{\mathrm{m}}=569\left(1-\mathrm{e}^{-0.0230 t}\right)$ & $\mathrm{N}_{\mathrm{m}}=286\left(1-\mathrm{e}^{-0.0802 t}\right)$ \\
\hline Troup & $\mathrm{N}_{\mathrm{m}}=59.7\left(1-\mathrm{e}^{-0.0640 t}\right)$ & $\mathrm{N}_{\mathrm{m}}=189\left(1-\mathrm{e}^{-0.0571 t}\right)$ & $\mathrm{N}_{\mathrm{m}}=185\left(1-\mathrm{e}^{-0.0709 t}\right)$ \\
\hline
\end{tabular}

${ }^{\dagger} \mathrm{N}_{\mathrm{m}}=$ organic $\mathrm{N}$ mineralized $\left(\mathrm{mg} \mathrm{kg}^{-1}\right)$ at specific time $(t)$.

TABLE 5: Comparison of calculated potentially mineralizable organic $\mathrm{N}$ pools $\left(N_{0}\right)$ in soils alone and soils amended with broiler litter 1 or 2 .

\begin{tabular}{|c|c|c|c|}
\hline Soil series & Soil alone ${ }^{\dagger}$ & $\begin{array}{l}\text { Soil + broiler litter } 1^{\dagger \dagger} \\
\mathrm{mg} \mathrm{NO}_{3}^{-} \mathrm{kg}^{-1}\end{array}$ & Soil + broiler litter $2^{\dagger \dagger}$ \\
\hline Appling & $85.3 c$ & $252 b$ & $283 a$ \\
\hline Cecil & $120 \mathrm{a}$ & $251 \mathrm{a}$ & $331 \mathrm{a}$ \\
\hline Colbert & $76.7 \mathrm{~cd}$ & $360 \mathrm{a}$ & $368 \mathrm{a}$ \\
\hline Decatur & $86.9 \mathrm{cb}$ & $356 a$ & $405 a$ \\
\hline Dothan & $66.9 \mathrm{ed}$ & $131 \mathrm{a}$ & $167 \mathrm{a}$ \\
\hline Hartsells & $47.9 \mathrm{f}$ & $208 \mathrm{a}$ & $294 a$ \\
\hline Linker & $102 b$ & $195 \mathrm{a}$ & $209 a$ \\
\hline Maytag & $82.8 \mathrm{~cd}$ & $221 \mathrm{a}$ & $217 \mathrm{a}$ \\
\hline Sucarnoochee & $123 a$ & $569 \mathrm{a}$ & $286 b$ \\
\hline Troup & $59.7 \mathrm{ef}$ & $189 \mathrm{a}$ & $185 \mathrm{a}$ \\
\hline
\end{tabular}

${ }^{\dagger}$ Means with the same letter in the soil alone column are not significantly different at $P<0.05$.

${ }^{\dagger}{ }^{\dagger}$ Means with the same letter in the same row of the broiler litter-amended soils are not significantly different at $P<0.05$.

a rapid mineralization of the easily mineralizable organic $\mathrm{N}$, followed by mineralization of the intermediate fraction, and finally the most resistant organic fraction where the curve tends to plateau with increasing incubation time. In addition, this $\mathrm{N}$ mineralization pattern can be attributed to the differences in chemical properties of the soils. Previous studies showed that generally, the amounts of $\mathrm{N}$ mineralized correlate with total N, total C, and microbial N [34-36].

The differences in $\mathrm{N}$ mineralized from the same broiler litter sample in two different soils (Figures $1(\mathrm{a})$ and 1(b)) suggest that $\mathrm{N}$ mineralization is dependent not only on organic $\mathrm{N}$ fractions in a given broiler litter sample, but also on soil properties. Furthermore, mineralization of $\mathrm{N}$ in the broiler litter samples behaved differently in Decatur (Figure 2(b)), Hartsells (Figure 3(b)), and Sucarnoochee (Figure 5(b)) soils. However, in Cecil (Figure 1(b)), Colbert (Figure 2(a)), Linker (Figure 4(a)), Maytag (Figure 4(b)), and Troup (Figure 5(b)), N mineraliztion of the broiler litter samples followed much closer trends.

Initially the broiler litter samples mineralized rapidly during the first 10 weeks following their addition to soils, especially in Appling (Figure 1(a)) and Decatur (Figure 2(b)) soils. Nitrogen mineralization was slow in Troup soil
(Figure 5(b)) containing $125 \mathrm{~g} \mathrm{~kg}^{-1}$ clay and $800 \mathrm{~g} \mathrm{~kg}^{-1}$ of sand, while the highest mineralization occurred in Decatur soil (Figure 2(b)) containing $900 \mathrm{~g} \mathrm{~kg}^{-1}$ sand and $100 \mathrm{~g} \mathrm{~kg}^{-1}$ silt. Mineralization of leguminous crops added to five Iowa soils incubated for 16 weeks at $30^{\circ} \mathrm{C}$ has been reported [33] and the results were similar to those discussed here.

The regression equations for organic $\mathrm{N}$ mineralized for the nonamended and amended soils are shown in Table 4 . The potentially mineralizable $\left(\mathrm{N}_{0}\right)$ organic $\mathrm{N}$ mineralized in the nonamended soils ranged from 47.9 to $123 \mathrm{mg} \mathrm{N} \mathrm{kg}^{-1}$ in Hartsells and Sucarnoochee soils, respectively. Hartsells soil showed the lowest $\mathrm{N}_{0}$ mineralized probably because of its texture (high clay and moderate sand contents) that restricted access of soil microorganisms to organic residues. Conversely, in a sandy soil such as Sucarnoochee soil in which pore spaces are larger microorganisms have greater access to organic $\mathrm{N}$ [3]. The potentially mineralizable organic $\mathrm{N}$ $\left(\mathrm{N}_{0}\right)$ released in soils amended with broiler litter 1 or 2 were significantly higher than in those nonamended. The $\mathrm{N}_{0}$ in soils amended with broiler litter 1 varied from $131 \mathrm{mg} \mathrm{kg}^{-1}$ in Dothan soil to $569 \mathrm{mg} \mathrm{kg}^{-1}$ in Sucarnoochee soil with a rate constant $(k)$ of 0.0877 and 0.0230 , respectively. Similarly, Dothan soil amended with broiler litter 2 had 


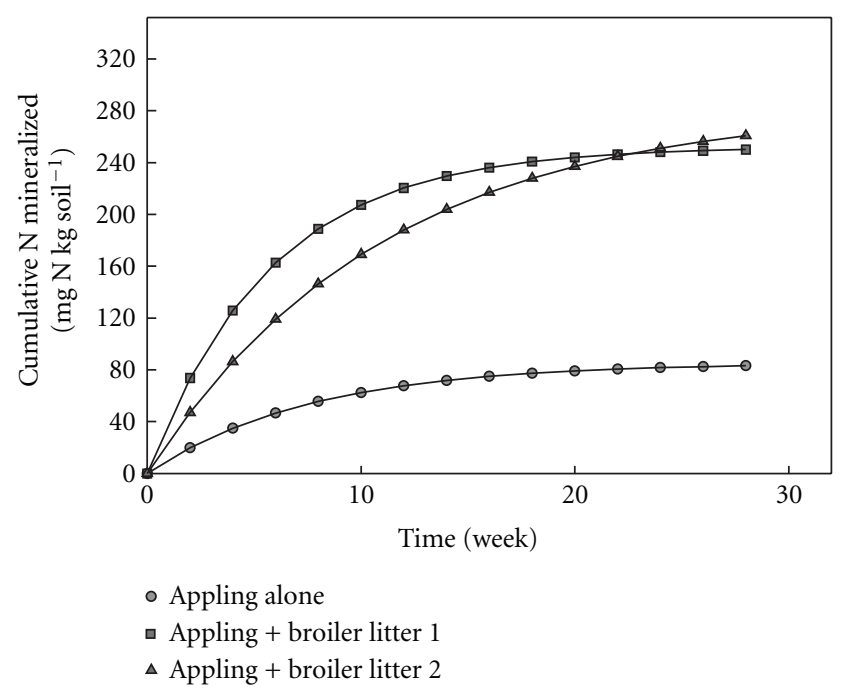

(a)

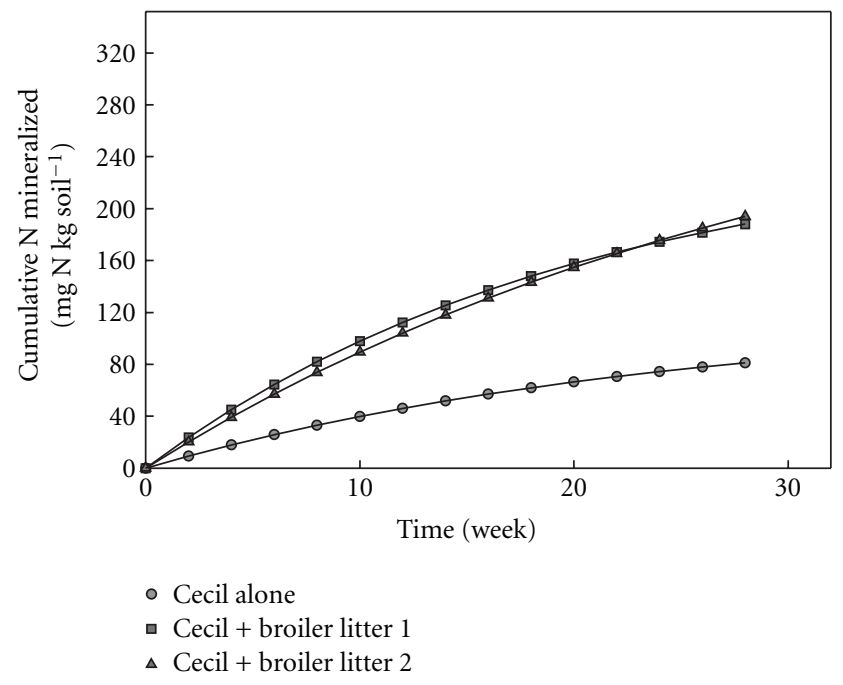

(b)

Figure 1: Cumulative organic nitrogen mineralized from Appling (a) or Cecil (b) soils amended with broiler litter 1 or 2 and incubated for 28 weeks under aerobic conditions.

the lowest potentially mineralizable organic $\mathrm{N}$ releasing $167 \mathrm{mg} \mathrm{kg}^{-1}$ soil with a rate constant of 0.0854 . However, Decatur soil amended with broiler litter 2 showed the highest potentially mineralizable $\mathrm{N}$ releasing $405 \mathrm{mg} \mathrm{kg}^{-1}$ soil with a rate constant of 0.0619 . Among the ten soil samples studied, soils amended with broiler litter 2 had the highest $\mathrm{N}_{0}$ as compared with those amended with broiler litter 1 with the exception of Maytag, Sucarnoochee, and Troup soils, which had greater $\mathrm{N}_{0}$ when amended with broiler litter 1. Statistical analysis of the complied $\mathrm{N}_{0}$ in Table 5 showed differences in the studied soils alone or amended with broiler litter. Among the nonamended soils, Appling, Colbert, Decatur, and Maytag soils showed no significant differences in $\mathrm{N}_{0}$ at $P<0.05$. Additionally, nonamended Cecil and Sucarnoochee soils $\left(\mathrm{N}_{0}=120\right.$ and $\mathrm{N}_{0}=$ $123 \mathrm{mg} \mathrm{N} \mathrm{kg}^{-1}$ soil, resp.) showed no significant difference at

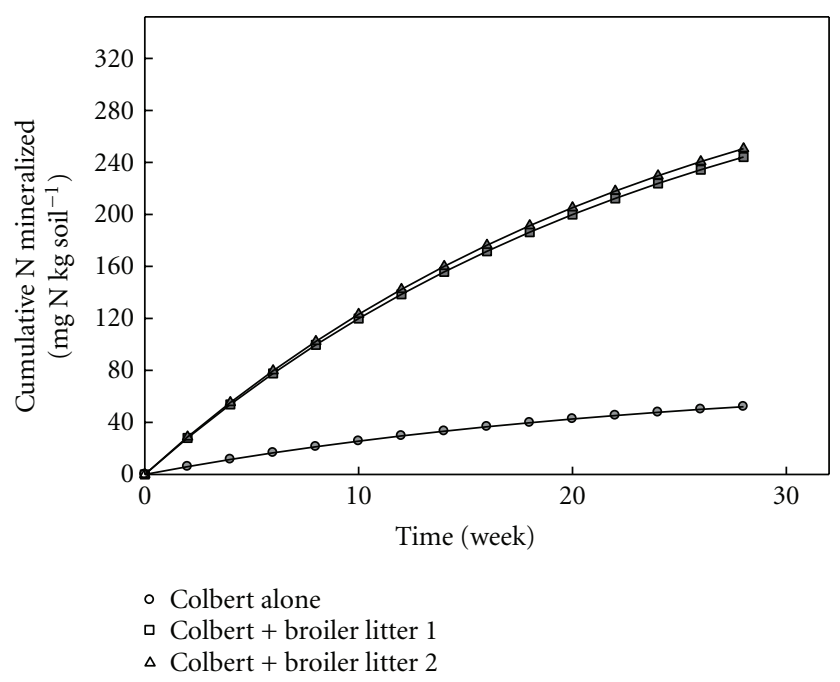

(a)

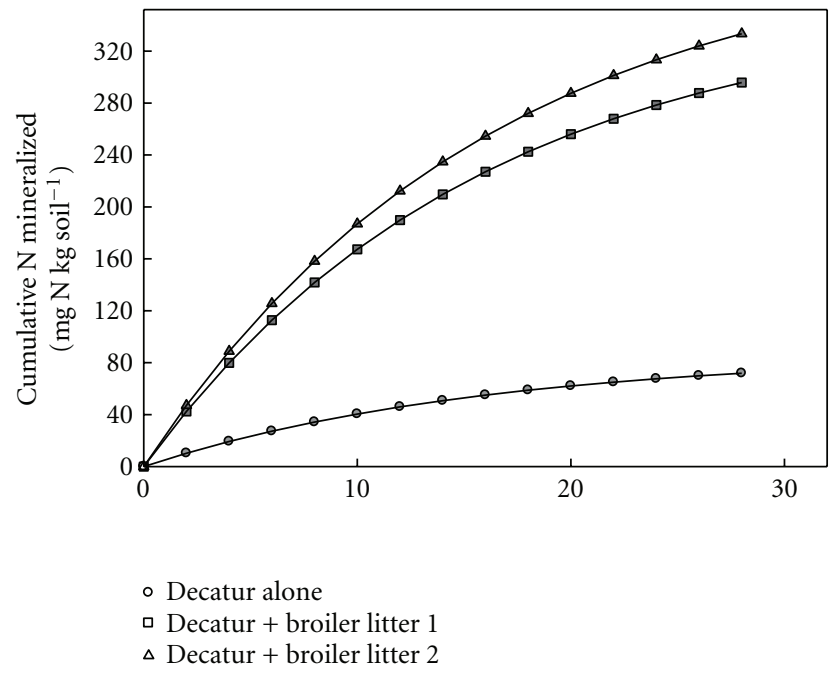

(b)

FIGURE 2: Cumulative organic nitrogen mineralized from Colbert (a) or Decatur (b) soils amended with broiler litter 1 or 2 and incubated for 28 weeks under aerobic conditions.

$P<0.05$. Furthermore, for soils amended with broiler litter 1 or 2 there were no significant differences detected between Cecil, Colbert, Decatur, Dothan, Hartsells, Linker, Maytag, and Troup soils. However, Appling and Sucarnoochee soils treated with broiler litter 1 or 2 showed significant differences at $P<0.05$. The broiler litter samples 1 and 2 added to the ten soils contained 27.5 and $46.1 \mathrm{~g} \mathrm{~kg}^{-1}$ of total $\mathrm{N}$, respectively (Table 2). The bedding material also varied in the broiler litter samples; broiler litter 1 consisted of pine sawdust and broiler litter 2 peanut hulls. Therefore, the results suggest that the bedding material (peanut hulls or pine sawdust) may not have a significant difference on the $\mathrm{N}_{0}$ pools.

3.3. Estimation of Mineralization Rate $\left(k_{i}\right)$ of Organic N. To identify the various phases involved in the mineralization of organic $\mathrm{N}$ and to estimate the mineralization rate $\left(k_{i}\right)$ 
TABLE 6: First-order rate constants for decomposition of organic $\mathrm{N}$ in soil alone and broiler litter-amended soils.

\begin{tabular}{|c|c|c|c|c|c|c|}
\hline \multirow{2}{*}{ Soil series } & \multirow{2}{*}{ Broiler Litter Sample ID } & \multicolumn{2}{|c|}{ Decomposition rate $\left(\text { week }^{-1}\right)^{\dagger}$} & \multicolumn{2}{|c|}{ Percentage of $\mathrm{N}$ mineralized at each Phase } & \multirow{2}{*}{$\begin{array}{c}\text { Half-life of } \mathrm{N} \\
\text { Remaining (weeks) }\end{array}$} \\
\hline & & $k_{1}$ & $k_{2}$ & $D_{1}$ & $D_{2}$ & \\
\hline Appling & none & 0.00132 & 0.0003 & 6.73 & 1.38 & 75 \\
\hline Cecil & none & 0.0127 & 0.0019 & 3.54 & 2.01 & 52 \\
\hline Colbert & none & 0.004 & 0.002 & 2.27 & 1.34 & 50 \\
\hline Decatur & none & 0.003 & 0.001 & 6.03 & 1.57 & 33 \\
\hline Dothan & none & 0.006 & 0.002 & 3.80 & 1.78 & 50 \\
\hline Hartsells & none & 0.0015 & 0.0006 & 1.85 & 0.78 & 66 \\
\hline Linker & none & 0.007 & 0.003 & 5.10 & 0.37 & 33 \\
\hline Maytag & none & 0.0105 & 0.0016 & 4.15 & 1.43 & 62 \\
\hline Sucarnoochee & none & 0.012 & 0.001 & 4.68 & 2.31 & 38 \\
\hline Troup & none & 0.0025 & 0.0026 & 2.49 & 0.95 & 40 \\
\hline Appling & 1 & 0.0065 & 0.0023 & 18.8 & 1.10 & 15 \\
\hline Cecil & 1 & 0.0026 & 0.0014 & 17.7 & 1.86 & 38 \\
\hline Colbert & 1 & 0.0038 & 0.0025 & 18.2 & 3.32 & 26 \\
\hline Decatur & 1 & 0.004 & 0.0018 & 11.3 & 2.40 & 25 \\
\hline Dothan & 1 & 0.0028 & 0.0015 & 14.1 & 1.25 & 35 \\
\hline Hartsells & 1 & 0.003 & 0.0014 & 20.7 & 2.29 & 33 \\
\hline Linker & 1 & 0.0036 & 0.0012 & 20.4 & 2.32 & 28 \\
\hline Maytag & 1 & 0.0044 & 0.0015 & 19.7 & 2.43 & 23 \\
\hline Sucarnoochee & 1 & 0.003 & 0.0029 & 17.5 & - & 33 \\
\hline Troup & 1 & 0.0023 & 0.00115 & 5.55 & 1.37 & 43 \\
\hline Appling & 2 & 0.0039 & 0.0012 & 51.1 & 1.49 & 25 \\
\hline Cecil & 2 & 0.0028 & 0.0014 & 29.9 & - & 35 \\
\hline Colbert & 2 & 0.0031 & 0.0021 & 19.7 & 3.49 & 32 \\
\hline Decatur & 2 & 0.0045 & 0.002 & 17.8 & 3.41 & 22 \\
\hline Dothan & 2 & 0.0029 & 0.0018 & 33.7 & 1.56 & 34 \\
\hline Hartsells & 2 & 0.0043 & 0.0021 & 28.6 & 2.69 & 23 \\
\hline Linker & 2 & 0.0035 & 0.0014 & 26.6 & 2.58 & 28 \\
\hline Maytag & 2 & 0.0044 & 0.0013 & 35.3 & 2.36 & 23 \\
\hline Sucarnoochee & 2 & 0.0049 & 0.0018 & 28.7 & 2.93 & 20 \\
\hline Troup & 2 & 0.0025 & 0.00095 & 18.5 & 1.29 & 40 \\
\hline
\end{tabular}

${ }^{\dagger} k_{1}$ and $k_{2}$ were calculated from graphs prepared by plotting organic $\mathrm{N}$ remaining after each incubation time against time. No second phase was identified in Sucarnoochee and Cecil soils amended with broiler litter 2.

of the various organic $\mathrm{N}$ pools in the broiler litter, graphs were constructed by plotting the natural log of $\mathrm{N}$ remaining against incubation time (weeks) for the data collected. With the exception of Appling soil which showed three-phase decomposition, all other soils showed two-phase decomposition model and an example is provided in Figure 6 for two soils. In phase I $\left(k_{1}\right)$, soil microorganisms mineralized quickly the easily mineralizable fraction in broiler litter; in phase II $\left(k_{2}\right)$ a more resistant fraction of organic $\mathrm{N}$ is being mineralized, thus, mineralization rate slowed down. Finally, during phase III $\left(k_{3}\right)$, soil microorganisms are mineralizing the most resistant fraction of organic N. A study conducted in three soil types concluded that soil type had a significant impact on broiler litter mineralization [37].

The half-life of $\mathrm{N}$ remaining corresponds to the amount of time required to mineralize half of the potentially mineralizable organic $\mathrm{N}$ (Table 6). Therefore, the higher the half-life of $\mathrm{N}$ remaining is, the slower the mineralization rate. The transformation of $\mathrm{N}$ mineralization data showed that the decomposition of organic $\mathrm{N}$ from broiler litter amended soils occurred in two phases as shown by $D_{1}$ and $D_{2}$. The percentage of $\mathrm{N}$ mineralized in the nonamended soils during phase I varied from $1.85 \%$ in Hartsells soil to $6.73 \%$ in Appling soil, respectively. However, in the same nonamended Hartsells and Appling soils, the percentages of organic $\mathrm{N}$ in phase II were only $0.78 \%$ and $1.38 \%$, respectively. Again, in Appling soil amended with broiler litter 1, the organic $\mathrm{N}$ mineralized was $18.8 \%$ and $1.10 \%$ in phases I and II, respectively. With respect to soils amended with broiler litter 2, Appling soil mineralized $51.1 \%$ and $1.49 \%$, of organic $\mathrm{N}$ in phases I, and II, respectively. Since the nonamended soils consist of a more resistant fraction of organic $\mathrm{N}$, it was not easily mineralized by soil microbes; the values of organic $\mathrm{N}$ remaining in the nonamended soils were high. Similarly, the 


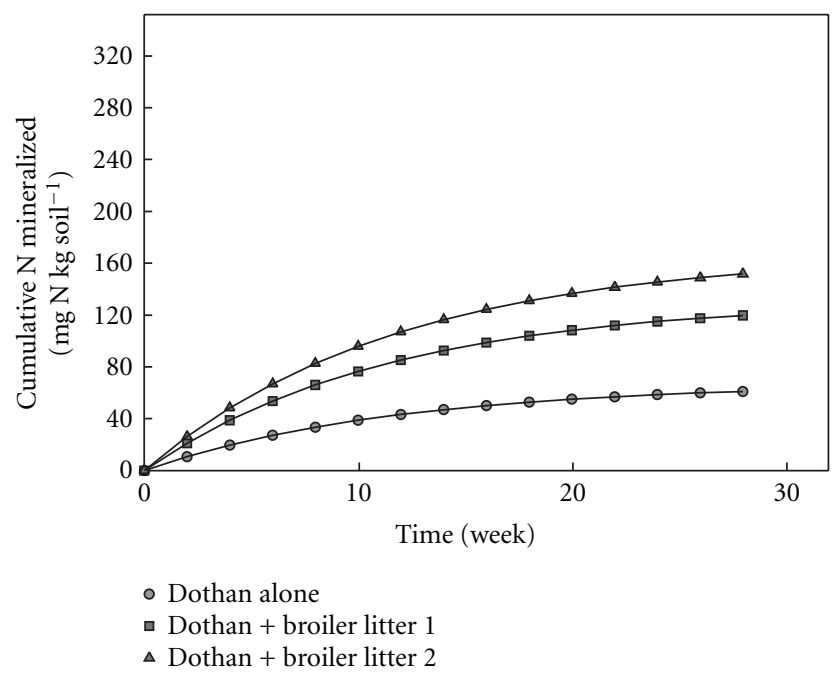

(a)

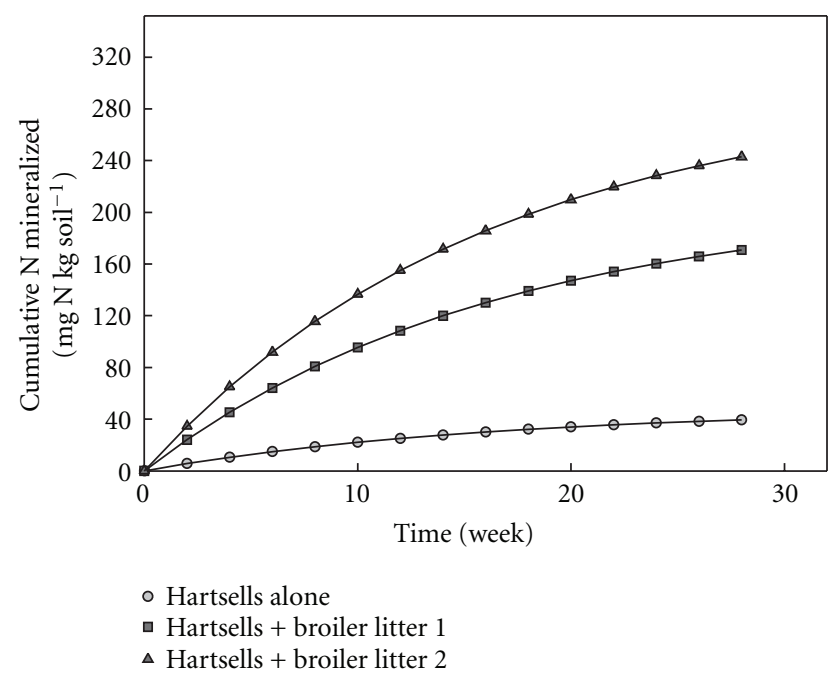

(b)

Figure 3: Cumulative organic nitrogen mineralized from Dothan (a) or Hartsells (b) soils amended with broiler litter 1 or 2 and incubated for 28 weeks under aerobic conditions.

half-life of $\mathrm{N}$ remaining in nonamended soils varied from 33 weeks in Decatur and Linker soils to 75 weeks in Appling soil. In addition, Appling and Maytag soils amended with broiler litter 1 and 2 showed significantly lower half-lives with 15 and 23 weeks when amended with broiler litter 1 , and 25 and 23 weeks when amended with broiler litter 2, respectively. Moreover, the half-life of $\mathrm{N}$ remaining in the soils varied considerably with broiler litter samples and differences in soil type.

3.4. Relationships of Potentially Mineralizable Organic $N\left(N_{0}\right)$ and Soil Properties. Linear regression lines show relationships between potentially mineralizable organic $\mathrm{N}\left(\mathrm{N}_{0}\right)$ soil textures (Figure 7). There are a number of factors that affect the amount of available $\mathrm{N}$ in a soil for plant uptake. Some of these factors include soil properties such as texture,

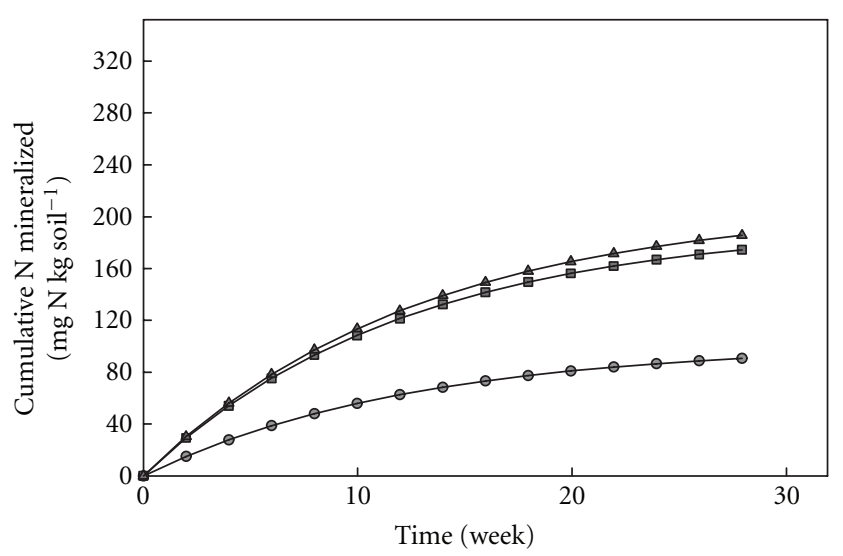

- Linker alone

- Linker + broiler litter 1

$\Delta$ Linker + broiler litter 2

(a)

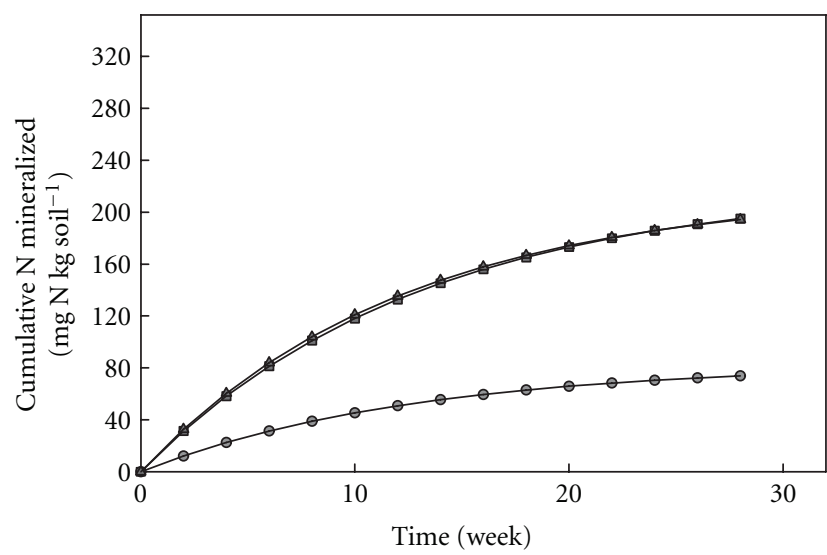

- Maytag alone

- Maytag + broiler litter 1

$\Delta$ Maytag + broiler litter 2

(b)

FIGURE 4: Cumulative organic nitrogen mineralized from Linker (a) or Maytag (b) soils amended with broiler litter 1 or 2 and incubated for 28 weeks under aerobic conditions.

structure, temperature, $\mathrm{pH}$, and organic matter content [38]. Other factors which affect $\mathrm{N}$ mineralization of broiler litter in soils include $\mathrm{C} / \mathrm{N}$ ratio, particle size, $\mathrm{pH}$ of the litter, type of bedding material, and soluble $\mathrm{N}$ fractions of the litter [25]. The slopes of the linear curves are negative and imply that high silt and clay contents reduce $\mathrm{N}_{0}$. However, high sand content accelerates mineralization of organic $\mathrm{N}$ in soils. A strong positive correlation $\left(r=0.874^{* * *}\right)$ between potentially mineralizable organic $\mathrm{N}\left(\mathrm{N}_{0}\right)$ and sand content was observed. However, correlations between $\mathrm{N}_{0}$ and both silt $\left(r=0.780^{* * *}\right)$ and clay $\left(r=0.983^{* * *}\right)$ were strongly negative. Influence of soil type and texture on $\mathrm{N}$ mineralization has been reported [39, 40]. These studies suggested that soils with relatively high silt and clay contents may have less ability to mineralize $\mathrm{N}$ than soils with high sand content, that promotes $\mathrm{N}$ mineralization. Nitrogen 


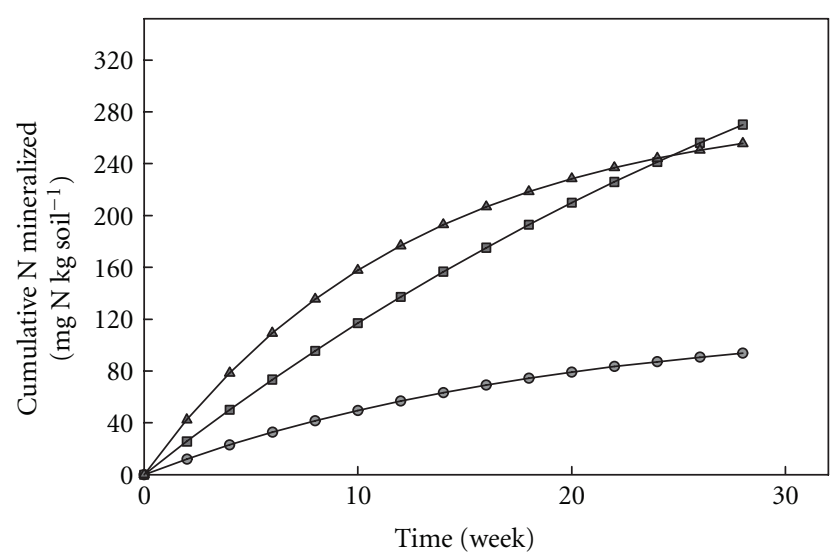

- Sucarnoochee alone

- Sucarnoochee + broiler litter 1

$\Delta$ Sucarnoochee + broiler litter 2

(a)

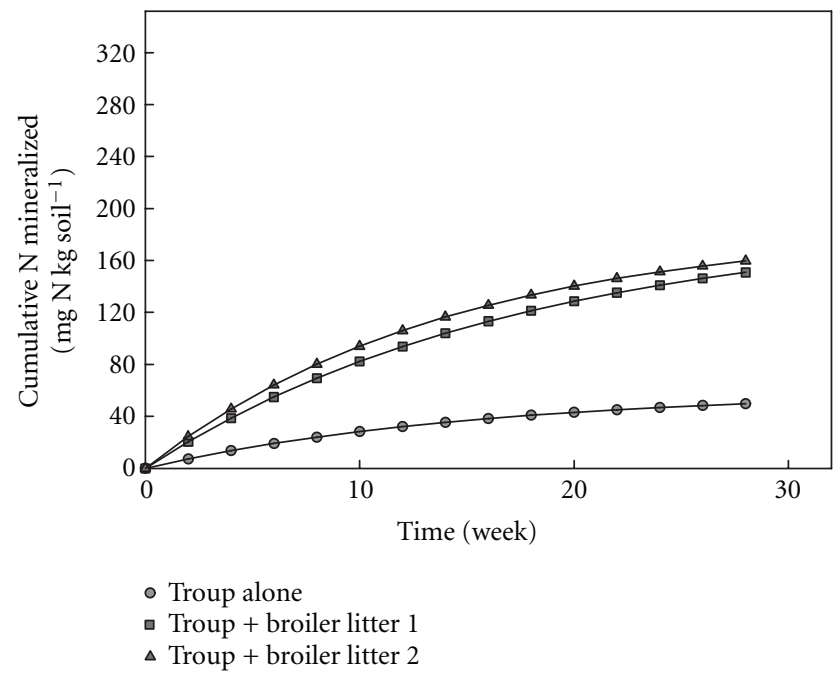

(b)

Figure 5: Cumulative organic nitrogen mineralized from Sucarnoochee soil (a) or Troup (b) soils amended with broiler litter 1 or 2 and incubated for 28 weeks under aerobic conditions.

mineralization potential in five important agricultural soils of Hawaii showed that the amount and type of clay in a soil affects mineralization processes [3]. Finely textured soils with high clay content have many tiny micropores in which organic matter can find physical protection from microbial decomposition. These results also agree with those reported in nine soils amended with broiler litter that showed a strong positive correlation with sand and a negative correlation with silt and clay contents of the soils [41]. In addition, this study shows a positive correlation $\left(r=0.782^{* *}\right)$ between $\mathrm{N}_{0}$ and soil organic $\mathrm{N}$ (Figure $8(\mathrm{a}))$ and soil organic $\mathrm{C}\left(r=0.884^{* * *}\right.$ Figure $8(\mathrm{~b})$ ). A positive correlation between $\mathrm{C} / \mathrm{N}$ ratio and $\mathrm{N}$ mineralization $(r=0.69)$ was reported [42] but contradicted another study that reported no relationship between manure $\mathrm{C} / \mathrm{N}$ ratios and $\mathrm{N}$ mineralization for a range of stored and fresh animal manures [43]. In this study also no significant

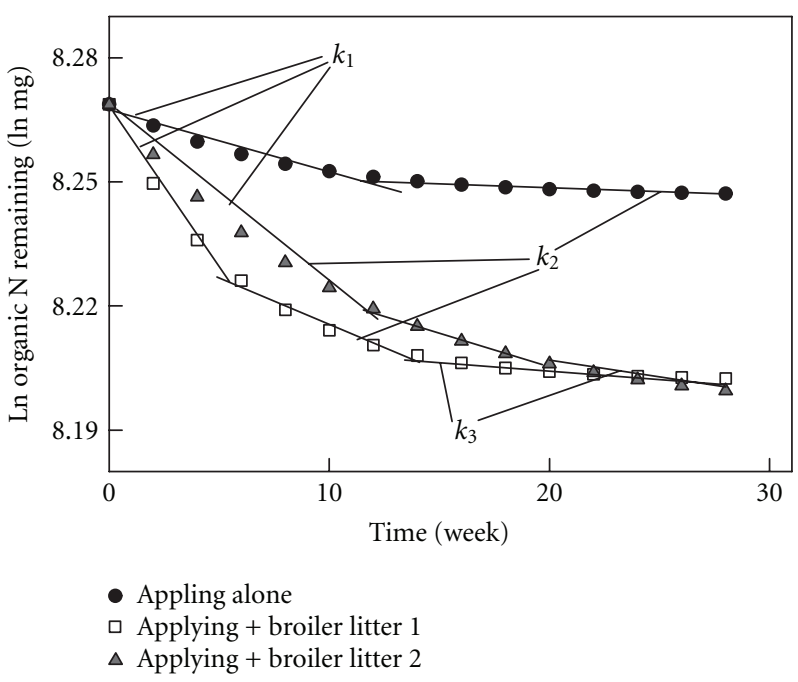

(a)

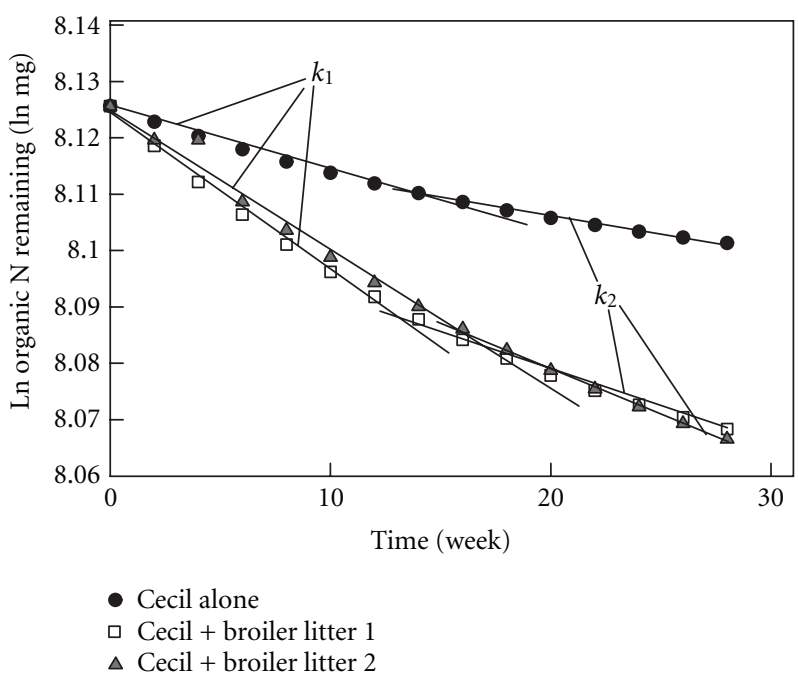

(b)

FIGURE 6: Natural log of organic N remaining in Appling (a) or Cecil (b) soils amended with broiler litter 1 or 2 as a function of time.

relationship was found between $\mathrm{N}_{0}$ and $\mathrm{C} / \mathrm{N}$ ratio (data not shown).

\section{Summary and Conclusions}

Investigation of the mineralization of native $\mathrm{N}$ and added broiler litter as $\mathrm{N}$ source to soils clearly demonstrated that soil type impacts $\mathrm{N}$ mineralization. The mineralization of native or added broiler litter conformed to a first-order kinetic reaction but varied considerably with soil type and broiler litter samples. Broiler litter samples 1 and 2 mineralized different quantities of organic $\mathrm{N}$ from the ten soils studied. This indicates that organic $\mathrm{N}$ fractions in different broiler litter samples are not the same. Notably, the amounts of organic N mineralized from the same broiler litter sample in two different soil types suggest that organic $\mathrm{N}$ mineralized from the different 


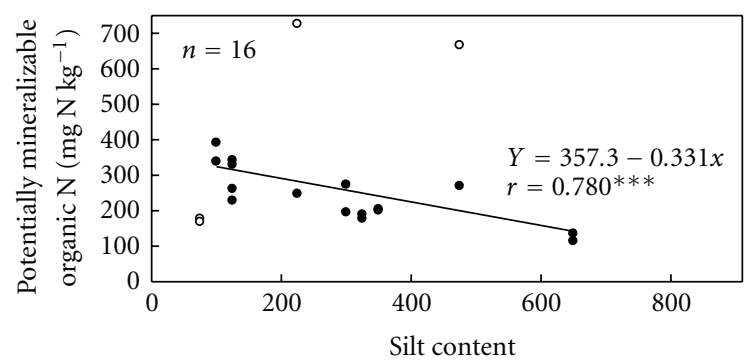

(a)

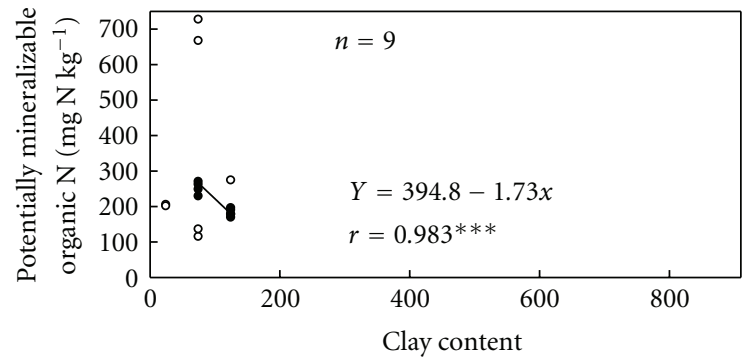

(b)

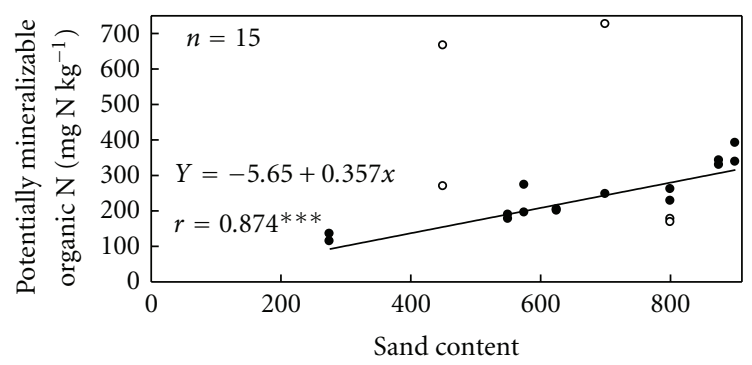

(c)

FIGURE 7: Relationships between potentially mineralizable organic nitrogen $\left(\mathrm{N}_{0}\right)$ and silt (a), clay (b), and sand (c) contents for soils amended with broiler litter 1 or 2 . The open circles did not fit the relationships.

broiler litter samples are dependent not only on organic $\mathrm{N}$ fractions in the broiler litter, but also on soil properties. Statistical analyses indicated that nonamended soil samples have differences in their ability to mineralize native organic N. However, among the ten soils studied only Appling and Sucarnoochee soils amended with broiler litter 1 or 2 showed significant differences at $P<0.05$. The differences in the $\mathrm{N}_{0}$ of the nonamended soils were obvious. The bedding materials varied in the broiler litter samples used in the study; broiler litter 1 consisted of pine sawdust and broiler litter 2 peanut hulls. The results suggested that the bedding material (peanut hulls or pine sawdust) may not have a significant difference on the $\mathrm{N}_{0}$ pools. The decomposition of organic $\mathrm{N}$ from broiler litter amended soils occurred mainly in two phases represented by $D_{1}$, and $D_{2}$. Half-life of $\mathrm{N}$ remaining in the nonamended soils was significantly higher than that of soils amended with broiler litter 1 or 2 suggesting that the nonamended soils consisted of a very resistant organic $\mathrm{N}$ fraction that could not be easily mineralized by soil microbes. However, in the amended soils, the half-life was significantly

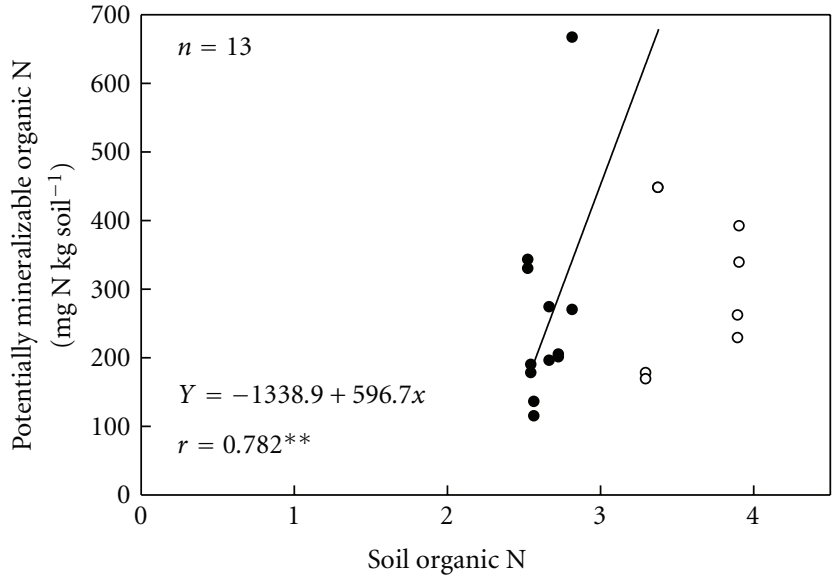

(a)

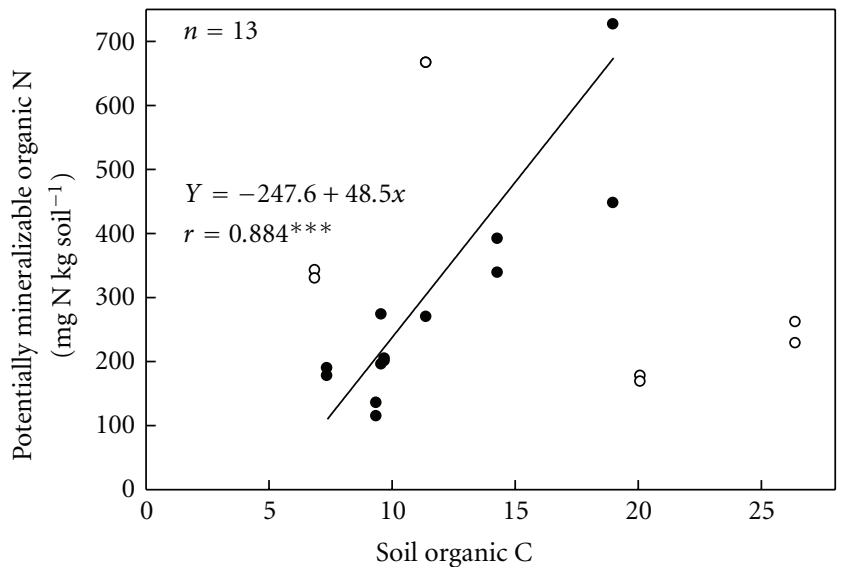

(b)

Figure 8: Relationships between potentially mineralizable organic nitrogen $\left(\mathrm{N}_{0}\right)$ and soil organic nitrogen (a) and soil organic carbon (b) in soils amended with broiler litter 1 or 2 . The open circles did not fit the relationship.

lower and varied with broiler litter samples and soil types. The results also demonstrated that mineralization of broiler litter in soils is closely related to soil chemical and physical properties. Thus, decomposition of organic residues and animal waste in soils vary with waste and soils types and must be investigated in an effort to synchronize $\mathrm{N}$ release with crop demand and protect the environment from excess nitrate accumulation.

\section{References}

[1] P. A. Moore, T. C. Daniel, D. R. Edwards, and D. M. Miller, "Effect of chemical amendments on ammonia volatilization from poultry litter," Journal of Environmental Quality, vol. 24, no. 2, pp. 293-300, 1995.

[2] J. A. Delgado, Potential Use of Innovative Nutrient Management Alternatives to Increase Nutrient Use Efficiency, Reduce Losses, and Protect Soil and Water Quality, Special Issue of the Journal of Communications in Soil Science and Plant Analysis, Marcel Dekker, New York, NY, USA, 2001. 
[3] J. Deenik, Nitrogen Mineralization Potential in Important Agricultural Soils of Hawaii, Soil and Crop Management, Cooperative Extension Service, 2006.

[4] Nutrition Business Journal, Organic Trade Association (OTA), Greenfield, Mass, USA, 2006, http://www.ers.usda.gov/publications/eib55/eib55ref.pdf.

[5] United States Department of Agriculture: Economic Research Services, 2009, http://www.nal.usda.gov/Briefing/Organic/ Questions/farmersmarkets.htm/.

[6] K. P. Paudel and C. S. McIntosh, "Country report: Broiler industry and broiler litter-related problems in the southeastern United States," Waste Management, vol. 25, no. 10, pp. 1083-1088, 2005.

[7] National Agricultural Statistics Service, Poultry-Production and Value 2007. Summary, United States Department of Agriculture National Agricultural Statistics Service, 2008.

[8] J. S. Robinson and A. N. Sharpley, "Water quality: release of nitrogen and phosphorus from poultry litter," Journal of Environmental Quality, vol. 24, no. 1, pp. 62-67, 1995.

[9] United States Department of Agriculture: National Agriculture Statistic Service, 2010, http://www.nass.usda.gov/Charts and_Maps/Poultry/brlmap.asp.

[10] K. Kpomblekou-A, "Relative proportion of inorganic and total nitrogen in broiler litter as determined by various methods," Journal of the Science of Food and Agriculture, vol. 86, no. 14, pp. 2354-2362, 2006.

[11] H. O. Liechty, M. A. Blazier, J. P. Wight, L. A. Gaston, J. D. Richardson, and R. L. Ficklin, "Assessment of repeated application of poultry litter on phosphorus and nitrogen dynamics in loblolly pine: implications for water quality," Forest Ecology and Management, vol. 258, no. 10, pp. 22942303, 2009.

[12] K. Kpomblekou-A, R. O. Ankumah, and H. A. Ajwa, "Trace and nontrace element contents of broiler litter," Communications in Soil Science and Plant Analysis, vol. 33, no. 11-12, pp. 1799-1811, 2002.

[13] C. C. Bitzer and J. T. Sims, "Estimating the availability of nitrogen in poultry manure through laboratory and field studies," Journal of Environmental Quality, vol. 17, no. 1, pp. 47-54, 1988.

[14] P. de Willigen, "Nitrogen turnover in the soil-crop system; comparison of fourteen simulation models," Fertilizer Research, vol. 27, no. 2-3, pp. 141-149, 1991.

[15] W. J. Wang, C. J. Smith, and D. Chen, "Predicting soil nitrogen mineralization dynamics with a modified double exponential model," Soil Science Society of America Journal, vol. 68, no. 4, pp. 1256-1265, 2004.

[16] N. G. Juma, E. A. Paul, and B. Mary, "Kinetic analysis of net nitrogen mineralization in soil.," Soil Science Society of America Journal, vol. 48, no. 4, pp. 753-757, 1984.

[17] F. E. Broadbent, "Empirical modeling of soil nitrogen mineralization.," Soil Science, vol. 141, no. 3, pp. 208-213, 1986.

[18] B. H. Ellert and J. R. Bettany, "Comparison of kinetic models for describing net sulfur and nitrogen mineralization," Soil Science Society of America Journal, vol. 52, no. 6, pp. 16921702, 1988.

[19] G. Stanford and S. J. Smith, "Nitrogen mineralization potentials of soils," Soil Science Society of America Journal, vol. 109, pp. 190-196, 1972.

[20] J. A. E. Molina, C. E. Clapp, and W. E. Larson, "Potentially mineraizable nitrogen in soil: the simple exponential model does not apply to the first 12 weeks of incubation," Soil Science Society of America Journal, vol. 44, pp. 442-443, 1980.
[21] L. J. Mebius, "A rapid method for the determination of organic carbon in soil," Analytica Chimica Acta, vol. 22, no. C, pp. 120124, 1960.

[22] J. M. Bremmer and C. S. Mulvaney, "Nitrogen-total," in Agronomy, A. L. Page, H. R. Miller, and D. R. Keeney, Eds., vol. 9, part 2, pp. 595-624, American Society of Agronomy, Madison, Wis, USA, 2nd edition, 1982.

[23] D. R. Keeny and D. W. Nelson, "Nitrogen-Inorganic forms," in Agronomy, A. L. Page, R. H. Miller, and R. D. Keeney, Eds., vol. 9, part 2, pp. 642-698, American Society of Agronomy, Madison, Wis, USA, 2nd edition, 1982.

[24] V. J. Kilmer and J. T. Alexander, "Method of making mechanical analysis of soils," Soil Science Society of America Journal, vol. 48, pp. 753-757, 1949.

[25] A. Sissoko and K. Kpomblekou-A, "Carbon decomposition in broiler litter-amended soils," Soil Biology and Biochemistry, vol. 42, no. 4, pp. 543-550, 2010.

[26] J. L. Smith, R. R. Schobel, B. L. McNeal, and G. S. Campbell, "Potential errors in the first-order model for estimating soil nitrogen mineralization potentials," Soil Science Society of America Journal, vol. 44, pp. 996-1000, 1980.

[27] A. J. Barr, J. H. Goodnight, J. P. Sall, and J. I. Helwig, A User's Guide to SAS, SAS Institute, Raleigh, NC, USA, 1976.

[28] C. M. Gilmour, F. E. Broadbent, and S. M. Beck, "Recycling of carbon and nitrogen through land disposal of various wastes," in Soils for Management of Organic Wastes and Waste Waters, L. E. Elliot and F. J. Stevenson, Eds., Soil Science Society of America, 1977.

[29] SAS Institute, SAS User's Guide, SAS Institute, New York, NY, USA, 1990.

[30] D. W. Marquardt, "An algorithm for least squares estimation of non-linear parameters," Journal of Society of Applied Mathematic, vol. 45, pp. 431-441, 1963.

[31] F. J. Stevenson, "Origin and distribution of nitrogen in soil," in Nitrogen in Agricultural Soils, F. J. Stevenson, Ed., pp. 1-42, Agronomy Society of America, Madison, Wis, USA, 1982.

[32] M. S. Coyne, Soil Microbiology: An Exploratory Approach, Delmar, New York, NY, USA, 1999.

[33] L. N. Nakhone and M. A. Tabatabai, "Nitrogen mineralization of leguminous crops in soils," Journal of Plant Nutrition and Soil Science, vol. 171, no. 2, pp. 231-241, 2008.

[34] G. M. Marion, J. Kummerow, and P. C. Miller, "Predicting nitrogen mineralization in chaparral soils," Soil Science Society of America Journal, vol. 45, pp. 956-961, 1981.

[35] I. J. Manguiat, I. Watanabe, G. B. Mascariña, and J. G. Tallada, "Nitrogen mineralization in tropical wetland rice soils: I. Relationship with temperature and soil properties," Soil Science and Plant Nutrition, vol. 42, no. 2, pp. 229-238, 1996.

[36] V. Z. Antonopoulos, "Comparison of different models to simulate soil temperature and moisture effects on nitrogen mineralization in the soil," Journal of Plant Nutrition and Soil Science, vol. 162, no. 6, pp. 667-675, 1999.

[37] K. R. Sistani, A. Adeli, S. L. McGowen, H. Tewolde, and G. E. Brink, "Laboratory and field evaluation of broiler litter nitrogen mineralization," Bioresource Technology, vol. 99, no. 7, pp. 2603-2611, 2008.

[38] K. H. Nahm, "Factors influencing nitrogen mineralization during poultry litter composting and calculations for available nitrogen," World's Poultry Science Journal, vol. 61, no. 2, pp. 238-255, 2005.

[39] P. Sorensen, E. S. Jensen, and N. E. Nielsen, "The fate of ${ }^{15} \mathrm{~N}-$ labelled organic nitrogen in sheep manure applied to soils of 
different texture under field conditions," Plant and Soil, vol. 162, no. 1, pp. 39-47, 1994.

[40] C. W. Honeycutt, T. S. Griffin, and Z. He, "Manure nitrogen availability: dairy manure in northeast and central U.S. soils," Biological Agriculture and Horticulture, vol. 23, no. 2, pp. 199214, 2005.

[41] R. M. Gordillo and M. L. Cabrera, "Mineralizable nitrogen in broiler litter: II. Effect of selected soil characteristics," Journal of Environmental Quality, vol. 26, no. 6, pp. 1679-1686, 1997.

[42] M. D. Serna and F. Pomares, "Comparison of biological and chemical methods to predict nitrogen mineralization in animal wastes," Biology and Fertility of Soils, vol. 12, no. 2, pp. 89-94, 1991.

[43] J. Z. Castellanos and P. F. Pratt, "Mineralization of manures nitrogen correlation with laboratory indexes," Soil Science Society of America Journal, vol. 45, pp. 354-357, 1981. 


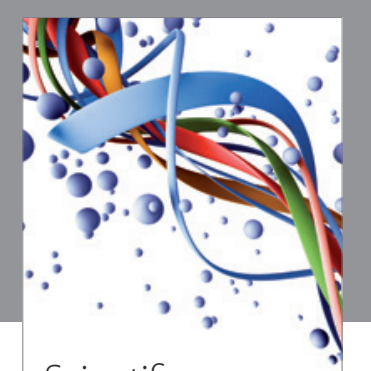

Scientifica
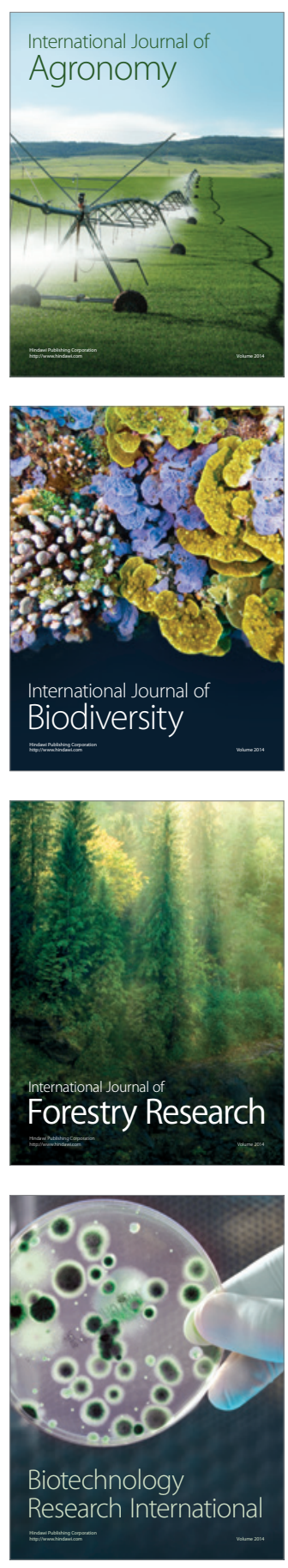
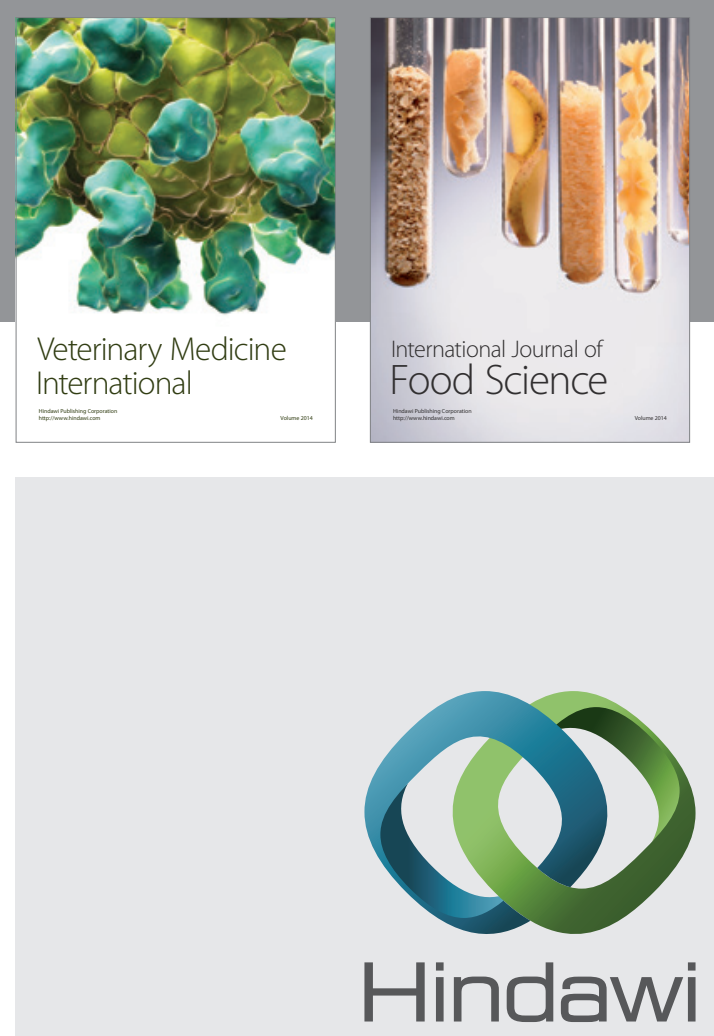

Submit your manuscripts at

http://www.hindawi.com
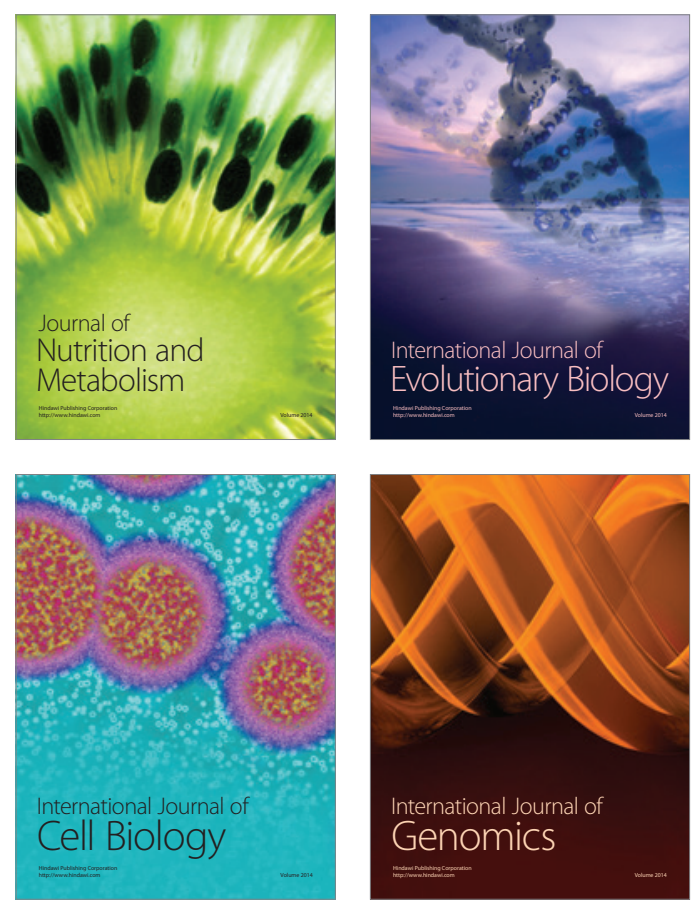
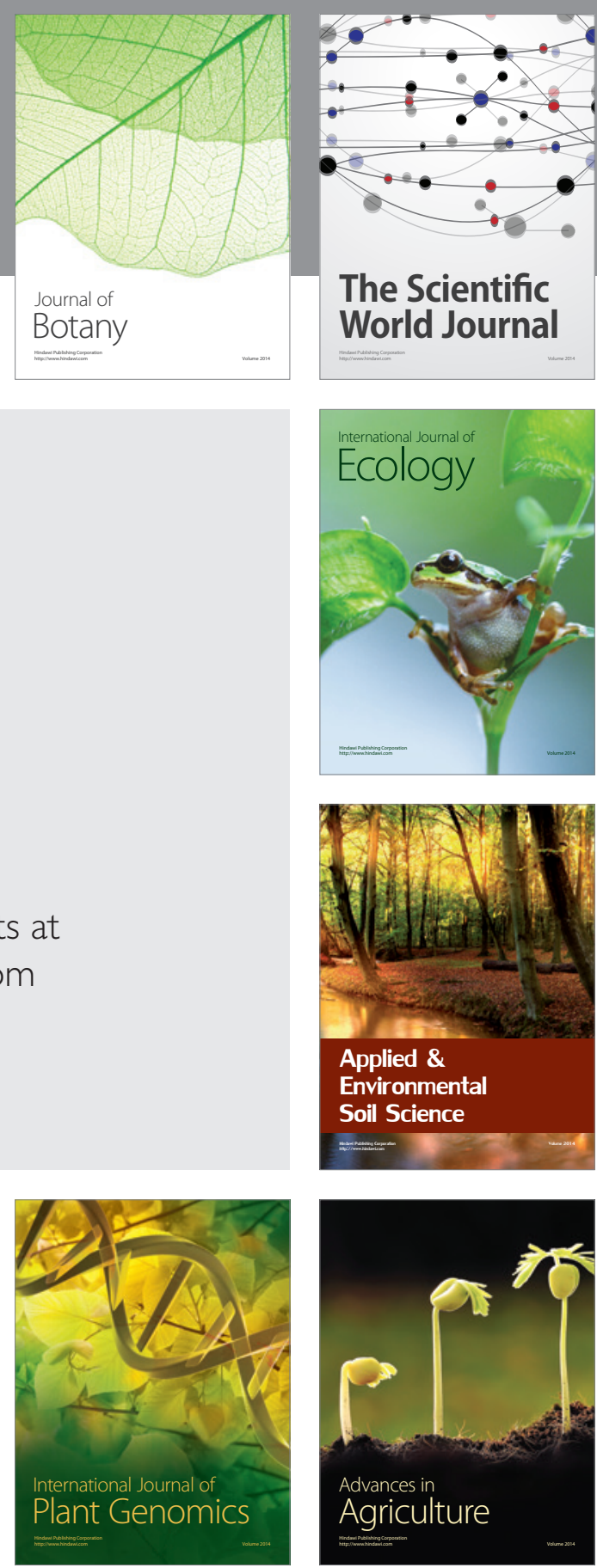

The Scientific World Journal
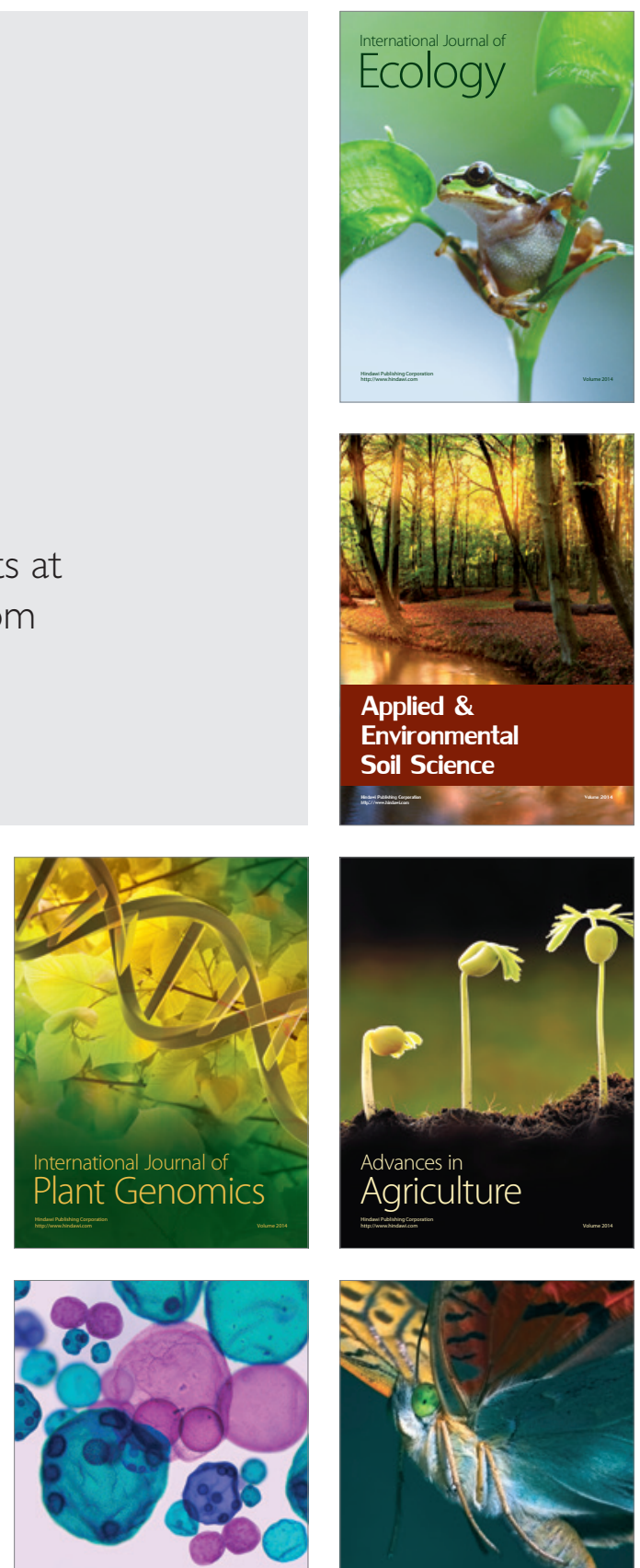

International Journal of Microbiology

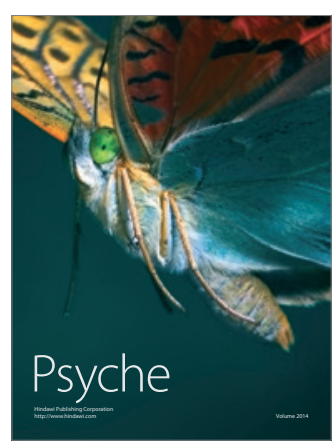

